\title{
Physical Activity Profile of Adolescence in the State of Qatar
}

\author{
G. Daradkeh ${ }^{1}$, Asma Al Muhannadi ${ }^{1}$, P. Chandra ${ }^{2}$, Moudi Al Hajr ${ }^{1}$, H. Al Muhannadi ${ }^{1}$ \\ ${ }^{1}$ Dietetics Dept. - A K H - HMC \\ ${ }^{2}$ Medical Research Dept. - HMC \\ Corresponding author: Ghazi Daradkeh - Hamad Medical Corporation - ALkhor Hospital - Qatar \\ gdaradkeh@hmc.org.qa
}

\begin{abstract}
:
Objectives: To assess the physical activity and inactivity behaviors among secondary school adolescents in the state of Qatar.

Methods: Self administered questionnaires were filled out by 1232 randomly selected students aged $15-18$ years, during March and April 2012.

Results: The prevalence of inactivity $(<1$ times/wk) was ranged from 9.3 to $42 \%$ among different type of activities, while the prevalence of active adolescents ranged from $1 \%$ to $12 \%$ among different type of activities. The sedentary behaviors which measured by total screen time was $65 \%$ which indicates high prevalence rate of inactivity according to (AAP) recommendations. Mean of Body Mass Index (BMI) was $25.5 \mathrm{~kg} / \mathrm{m}^{2}$ and 23.9 $\mathrm{Kg} / \mathrm{m}^{2}$ for males \& females respectively. Walking and / or running was the most participated by adolescents (76 $\%$ while self defense exercise was the lowest participated activity (16\%).The highest proportional of adolescents were took part activities either alone $28.8 \%$ or with friends $27.8 \%$, the most reason for being physically inactive was lack of time 62.5\%.All type of activities participated were lower among females than males except home works (gardening, floor cleaning and car washing).
\end{abstract}

Conclusion: Qatari adolescents are more likely to be inactive due to lack of time, suitable place \& / or facilities as well as lack of awareness about health benefits of exercise, so, Health Care Provider hand by hand with schools teacher have a vital role in promoting physical activity among adolescents in the state of Qatar.

Keywords: Physical activity, sedentary behaviors, Dietary habits, Lifestyle factors, Adolescents.

Physical activity is defined as any bodily movement produced by skeletal muscles that result in energy expenditure above basal level $(1,2)$. Regular physical activity has long been associated with a wide range of physical activity and mental health benefits $(2-10)$. On the other hand, physical inactivity has been considered $(3,5,6,11-13)$ one of the coronary artery disease (CAD) risk factors.

It appears that physical activity \& fitness are considered important components of public health measures (14). Many scientific, medical and public health organizations around the world have issued position statements on physical activity \& human health \& well being $(2,6,8,10,11,15)$.

According to the World Health Organization (WHO) Report 2002, the most important risks of Non Communicable Diseases (NCDs) included high blood pressure, high concentrations of cholesterol in the blood, inadequate intake of fruit and vegetables, being overweight or obese. Physical inactivity and tobacco use (16). Five of these risk factors are closely related to diet and physical activity. Thus, it is well recognized that diet and

Several researches have suggested that School Physical education (PE) programs and community recreation facilities are needed (33). Globally, non communicable diseases (NCDs) are the leading causes of death, killing more people each year than all other causes combined (34). Indeed, recent research findings have shown that television (TV) viewing (Sedentary activity) and physical activity appear to be separate entities and are independently associated with obesity and metabolic risk (35).

Qatar as other Eastern Mediterranean countries has tremendous life style are becoming particularly prevalent among Qatari children and youth. Data from a limited number of studies indicate that $60 \%$ of Saudi children and $71 \%$ of young people do not engage in physical activity of sufficient duration and frequency $(36,37)$. Due to lacking of such researches among Qatari adolescents, this paper presents finding on the physical activity profile of Qatari adolescence. 


\section{MethodS}

Questionnaire method was used in collecting information regarding physical activity pattern of adolescence in the state of Qatar. This method is considered most appropriate in large scale population studies, $(38,39)$. Extensive details on physical activity habits including type, frequency, duration and intensity were including in the questionnaire.

A multistage statistical random-sampling technique was used to select the sample. At the first stage, a systematic random sampling procedure was used to select the schools. The schools were stratified into boys and girls secondary schools, with further stratification in to public and private schools.

At the second stage, classes were selected at each grade (level) using simple random-sampling design. In this way, one third of sections were randomly selected in each of the three grades (grades 10, 11, 12) from each secondary school. Thus, we had a total selection of at least 57 classes (29 boys and 28 girls). All students in the selected classes, who were free of any physical health problems, were invited to participate in the study. The data were collected during March and April 2012. The study protocol was approved by the Research Committee at Hamad Medical Corporation as well as the Higher Supreme of Education in the State of Qatar.

In addition, all the schools and students consented to involvement in this study. The total sample size consisted of 1232 adolescents.

\section{ANTHRopometric MEASUREMENTS}

Body weight and height were measured in the morning by a trained researcher according to written standardized procedures. Body weight was measured to the nearest $100 \mathrm{gm}$ using electronic portable scales. Measurements were done with school uniform and without shoes. Height was measured to the nearest active is to maintain health $(35 \%)$ table 3 . While the most reasons for being physically inactive was lack of time $(62.5 \%)$, no suitable place $(9.9 \%)$, hesitate from others $(6.3 \%)$ and not satisfied with exercise benefits $(5.9 \%)$ table 4 . Further analysis of the data indicated that physical activity of all types was lower among females than males except homework's (gardening, floor cleaning and car washing).

The results indicate that, there is a significant difference between the intensity of all types of activity. The intensity of each activity was categorized as inactive for those who are didn't do any activity, moderately active (1-4 times / week) and active ( $\geq 5$ times / week). Table $2.41 \%$ and $40 \%$ of participants watched TV and used computer for more than 2 hours per day respectively, as a combination, the time of viewing TV and using computer more than 2 hours per day were found in 65 $\%$ of the subjects, that means only $35 \%$ of Qatari adolescents met the recommended screen time guidelines of 2 hours or less per day.

Table1. Descriptive Charecteristics of Subjects $(n=1230)$

\begin{tabular}{|l|l|l|l|}
\hline Variable & Male & $\begin{array}{l}\text { Female } \\
\text { N Mean } \pm \text { 5 D }\end{array}$ & P - value \\
\hline Age $(\mathrm{Yrs})$ & $62516.45 \pm 0.95$ & $60216.18 \pm 1.00$ & $<0.001$ \\
Weight $(\mathrm{Kg})$ & $62773.3 \pm 22.07$ & $60359.7 \pm 15.17$ & $<0.001$ \\
Height $(\mathrm{Cm})$ & $627169.09 \pm 7.08$ & $603157.97 \pm 6.31$ & $<0.001$ \\
BMI $\left(\mathrm{Kg} / \mathrm{m}^{2}\right)$ & $62725.56 \pm 7.30$ & $60323.89 \pm 5.65$ & $<0.001$ \\
W C $(\mathrm{Cm})$ & $62578.14 \pm 15.33$ & $60373.82 \pm 11.56$ & $<0.001$ \\
WHR & $6270.46 \pm 0.09$ & $6030.46 \pm 0.02$ & 0.432 \\
\hline
\end{tabular}

Physical activities play important roles in maintaining health and preventing diseases (17). Adolescent over weight is a major U S public health problem, with prevalence rates increasing for children and adolescents, (18). Inactivity and activity are important biological determinants of obesity \& represent major avenues for treating and preventing obesity $(19,20,21)$. Physical activity has been associated with a wide range of beneficial health outcomes in adults, including bone and cardiovascular health \& reduction of selected cancers (22). Inactivity, in particular, TV viewing, has been associated with obesity in cross - sectional studies of children, adolescents and adults (23). Physical activity habits, and specially, inactivity, track significantly from adolescence to young adult hood (24).

The physical activity literature has examined environmental determinants such as school and community sports and home access to fitness equipment $(25,26)$ perceived physical environments (27), outdoor play spaces (28), time spent outdoors (29,30), exercise opportunity(31), and "an environment that promotes excessive food intake and discourages physical activity (32). 
Centimeter using a calibrated measuring role while the subject was in a full standing position without shoes. Body Mass Index (BMI) was calculated as the ratio of weight in kilograms divided by the height squared in meters and waist circumference was measured at level midway between the lowest lateral border of the ribs and the uppermost lateral iliac crest using a tape measure, to the nearest 0.5 $\mathrm{cm}$ with the subject standing and following normal expiration.

The research instruments used for the collection of lifestyle information, including the first five items that researcher had to measure and record. These items included age, weight, height, waist circumference and the students' level of study. Items 6 to 34 dealt with physical activity. Items 35 to 37 were questions on sedentary activity.

The participants completed the questionnaire in their class rooms under the supervision of their teachers and in front of at least one of the research members. The questionnaire was designed to collect information on frequency, duration and intensity of a variety of light, moderate and vigorousintensity physical activities during a typical week. The physical activity questionnaire covered such as domains as transport and household, fitness and sports activities.

Sedentary activities, including time spent watching TV, playing video games, and computer use. Participants were asked to provide the average number of daily hours without differentiating between weekdays and weekends.

For the total screen time cut off points, we used the American Academy of Pediatrics guidelines of a maximum of 2 hours per day (40).

\section{Statistical Analysis}

Data was analyzed using the SPSS statistical program, Chi-square $\left(\mathrm{x}^{2}\right)$ tests were performed, and follow up tests were conducted as needed using the cross tabs procedures. Significance level at 0.05 was used.

\section{RESULTS}

1230 Subjects were included in this study $51 \%$ of them were males \& $49 \%$ were females with a mean age of 16 years of both gender, while the mean weight 73.3 and $59.7 \mathrm{~kg}$ for males \& females respectively. While BMI mean was $25.5 \mathrm{~kg} / \mathrm{m}^{2}$ for males \& $23.9 \mathrm{~kg} / \mathrm{m}^{2}$ for females and it was $78.1 \mathrm{~cm}$ \& $73.8 \mathrm{~cm}$ for WC among male \& female respectively. Overall, males were taller, heavier and had significantly heavier mean BMI value than females.

Table2. Type of Physical Activity among Qatari Adolescence:

\begin{tabular}{|c|c|c|c|c|c|}
\hline \multirow[t]{2}{*}{ Type of Exercise } & \multirow[b]{2}{*}{ Sex } & \multicolumn{3}{|l|}{ Activity Level } & \multirow[b]{2}{*}{ P - Value } \\
\hline & & $\begin{array}{l}\text { Inactivity } \\
<\quad 1 \text { time } \\
\text { /week }\end{array}$ & $\begin{array}{l}\text { Moderately Active } \\
1 \text { - } 4 \text { times /week }\end{array}$ & $\begin{array}{l}\text { Active } \\
\geq 5 \text { times /week }\end{array}$ & \\
\hline $\begin{array}{l}\text { Walking \& or Running } \\
\mathrm{n}=1230\end{array}$ & $\begin{array}{l}\mathrm{M} \\
\mathrm{F}\end{array}$ & $\begin{array}{l}114(9.3) \\
176(14.3)\end{array}$ & $\begin{array}{l}365(29.7) \\
356(28.9)\end{array}$ & $\begin{array}{l}147(12.0) \\
72(5.8)\end{array}$ & $<0.001$ \\
\hline $\begin{array}{l}\text { Bicycle } \\
\mathrm{n}=1230\end{array}$ & $\begin{array}{l}\mathrm{M} \\
\mathrm{F}\end{array}$ & $\begin{array}{l}380(30.9) \\
416(33.8)\end{array}$ & $\begin{array}{l}191(15.5) \\
169(13.7)\end{array}$ & $\begin{array}{l}56(4.5) \\
18(1.5)\end{array}$ & $<0.001$ \\
\hline $\begin{array}{l}\text { Swimming } \\
\mathrm{n}=1230\end{array}$ & $\begin{array}{l}\mathrm{M} \\
\mathrm{F}\end{array}$ & $\begin{array}{l}356(28.9) \\
456(37.1)\end{array}$ & $\begin{array}{l}236(19.2) \\
135(11.0)\end{array}$ & $\begin{array}{l}35(2.8) \\
12(1.0)\end{array}$ & $<0.001$ \\
\hline $\begin{array}{l}\text { Volley ball \& bowling } \\
\mathrm{n}=1229\end{array}$ & $\begin{array}{l}\mathrm{M} \\
\mathrm{F}\end{array}$ & $\begin{array}{l}157(12.8) \\
274(22.3)\end{array}$ & $\begin{array}{l}380(30.9) \\
298(24.2)\end{array}$ & $\begin{array}{l}89(9.7) \\
31(3.7)\end{array}$ & $<0.001$ \\
\hline $\begin{array}{l}\text { Foot ball, basket ball and } \\
\text { hand ball } \\
\mathrm{n}=1227\end{array}$ & $\begin{array}{l}\mathrm{M} \\
\mathrm{F}\end{array}$ & $\begin{array}{l}193(15.7) \\
379(30.9)\end{array}$ & $\begin{array}{l}336(27.4) \\
207(16.9)\end{array}$ & $\begin{array}{l}96(7.8) \\
16(1.2)\end{array}$ & $<0.001$ \\
\hline $\begin{array}{l}\text { Self defense: Judo, } \\
\text { Karate, Taekwondo } \\
\mathrm{n}=1224\end{array}$ & $\begin{array}{l}\mathrm{M} \\
\mathrm{F}\end{array}$ & $\begin{array}{l}499(40.6) \\
526(42.8)\end{array}$ & $\begin{array}{l}90(7.7) \\
64(5.2)\end{array}$ & $\begin{array}{l}33(2.7) \\
12(1.0)\end{array}$ & $<0.001$ \\
\hline $\begin{array}{l}\text { Body building } \\
\mathrm{n}=502\end{array}$ & $\begin{array}{l}\mathrm{M} \\
\mathrm{F}\end{array}$ & $\begin{array}{l}162(32.3) \\
161(32.1) \\
\end{array}$ & $\begin{array}{l}112(22.3) \\
18(3.6) \\
\end{array}$ & $\begin{array}{l}26(8.8) \\
5(1.00)\end{array}$ & $<0.001$ \\
\hline $\begin{array}{l}\text { Home work: } \\
\text { Gardening, Cleaning, } \\
\text { Car washing } \\
\mathrm{n}=721\end{array}$ & $\begin{array}{l}\mathrm{M} \\
\mathrm{F}\end{array}$ & $\begin{array}{l}277(22.5) \\
231(18.8)\end{array}$ & $\begin{array}{l}281(22.9) \\
283(23.0)\end{array}$ & $\begin{array}{l}68(5.5) \\
89(7.3)\end{array}$ & $<0.003$ \\
\hline
\end{tabular}




\section{G. Daradkeh et al.}

Physical characteristics of the subjects are shown in Table1. The type of physical activity most participated by adolescents was walking and / or running (76\%), volleyball and bowling (64\%), gardening and home work (58 \%), Soccer (53\%), Bicycle and body building (35\%), Swimming (34 $\%)$ and self defense (16\%), table 2. Furthermore, most of the adolescents took part in activities either alone $(28.8 \%)$ or with friends $(27.8 \%)$, while the lowest activity was took with parents $(2.8 \%)$. The most important reason for being physically.

Table3. Most important reasons for being physically active among Qatari Adolescence $(n=1221)$

\begin{tabular}{|l|l|l|}
\hline Reason & n & Percentage \\
\hline Maintaining Health & 369 & 30.2 \\
\hline Losing Weight & 284 & 23.3 \\
\hline To meet friends & 61 & 05.0 \\
\hline For competition & 95 & 7.8 \\
\hline Other reason & 158 & 12.9 \\
\hline Multiple reasons & 254 & 20.8 \\
\hline
\end{tabular}

Table4. Most important reasons for being physically inactive among adolescence in Qatar $(n=1224)$.

\begin{tabular}{|l|l|l|}
\hline Reason & n & Percentage \\
\hline Lack of time & 765 & 62.5 \\
\hline Not satisfied with exercise benefits & 72 & 5.9 \\
\hline No suitable place & 121 & 9.9 \\
\hline Hesitate from others & 77 & 6.3 \\
\hline Other reasons \& Multiple reasons & 133 & 15.4 \\
\hline Total & $\mathbf{1 2 2 4}$ & $\mathbf{1 0 0 \%}$ \\
\hline
\end{tabular}

\section{DISCUSSION}

Current recommendations from different document $(6,8,15)$ have all recommend for at least $30 \mathrm{~min}$ or more of moderate intensity physical activity, on most, preferably all, days of the week. However, the finding of this study shows a high prevalence of inactivity among randomly selected Qatari adolescents. The prevalence of inactivity (do not exercise) ranged from $23.6 \%$ to $83.7 \%$ for different types of activities falls below the current recommendation. While the prevalence of active adolescence (5 or more times / week) was ranged between 4.4 to 17.8 among different types of exercise. According to American Academy of pediatrics (AAP) recommendations of screen viewing $2 \mathrm{hrs}$ or less only $35 \%$ of Subjects were met these recommendations per day as definition for inactivity. This finding indicates that there is a need to reduce the time spent by adolescence on TV watching and computer use. This finding is better than the finding among Saudi adolescents which shows $16 \%$ of males \& less than $11 \%$ of females were met the AAP recommendations on daily screen time (41). The prevalence of sedentary behaviors found in the present study among Qatari adolescents was remarkably high. The American Academy of Pediatrics (AAP) has expressed concern about the amount of time that children and adolescents spend viewing TV and has issued guidelines recommending that screen time not exceed 2 hours per day (42). The study shows that prevalence of 2 - hrs or more TV watching and computer use among Qatari adolescents was $49 \%$ and $39.9 \%$ respectively, this result nearly the same with what was reported among Chinese boys \& girls aged 13 - 18 years $44.3 \%$ and $34.7 \%$ respectively (43). While it is less than the prevalence of total screen time 2 hrs or more among Canadian youth $82 \%$ of girls \& $86 \%$ of boys (44). The prevalence of watching TV more than 2 hours (49\%) was the same of which reported by Finns $(48 \%)$ and $(44 \%)$ among adolescents boys and girls respectively (45). The finding of this study have also indicated that around half of the samples were inactive due to lack of time and suitable space. Thus public policies and governmental efforts are needed to initiate and restructure physical and social environment to encourage active living and discourage sedentary habits among Qatari adolescents.

Researches on physical activity revealed that inactivity is a strong risk factor for coronary heart disease (CHD) as the 3 commonly accepted CHD risk factors, namely hypertension, hypercholesterolemia and cigarette smoking. Finally, new policies and legislative efforts are needed to encourage active lifestyle and discourage the sedentary habits. Higher supreme of education as well as health care provider has an important role to play in promoting physical activity among Secondary School Children in the state of Qatar. 


\section{REFERENCES}

[1] Caspersen C, Powell K, Chritenson G. Physical activity, exercise, and physical fitness: definitions and distinctions for health related research. Public Health Rep 1985; 100: 126- 131.

[2] U.S. Department of health and Human Services. Physical activity and Health: A report of the Surgeon General Atlanta, GA centers for Disease control and prevention (CDC), National centres for Chronic Disease Prevention and Health Promotion; 1996.

[3] Paffenbarger R, Hyde R, Wing A, Hsieh C. Physical activity, all -cause mortality, and longetivity of college alumini. N Engl J med 1986; 314: 605 - 613.

[4] Bouchard C, Shephard R, Stephens T, Sutton J, McPherson B, editors. Exercise, Fitness and Health - A consensus of current knowledge, Champaign, IL: Human kinetics; 1990.

[5] Centre for Disease Control and Prevention. Protective effect of physical activity on coronary heart disease. MMWR 1987; 36; 426 - 430.

[6] Fletcher G, Balady G, Blair S, Blumenthal J, Caspersen C, Chaitman B et al. Statement on exercise. Benefits and recommendations for physical activity programs for all Americans. Circulation 1996: 94: 867-862.

[7] Haskell W. Health consequences of physical activity: understanding and challenges regarding dose-response. Med Sci sports Exerc 1994; 26: 649 - 660.

[8] Pate R, Pratt M, Blair S, Haskell W, Macera C, Bouchard C et al. Physical activity and public health. A recommendation from the centres for disease control and Prevention and the American College of Sports medicine. J Am Med Assoc 1995; 273: 402 - 407.

[9] Blair S, Kohl H, Paffenbarger R, Clark D, Cooper K, Gibbons L. Physical fitness and all cause mortality. A prospective study of health men and women. J Am Med Asso 1989; 262: 23952401.

[10] The international Federation of Sports Medicine Position Statement: physical exercise - an important factor for health. The World of Sport Medicine 1989: 2: 24-25.

[11] Bijnen F, Caspersen C, Mostard W. Physical inactivity as a risk factor for coronary heart disease: a WHO and International Society and Federation of Cardiology position statement . Bull WHO 1994; 72:1-4.

[12] Morris J. Exercise in the prevention of coronary heart disease: today's best buy in public health. Med Sci Sports Exerc 1994; 26: 807 - 814.

[13] World Health Organization (WHO). Active living-the challenge head: Developing active living policies and programs in over 50 countries by the end of 2001. Geneva: WHO; 1999.

[14] Mc Ginnis J. The public health burden of a sedentary lifestyle. Med Sci Sports Exerc 1992; 24 (suppl): S196-S200.

[15] Blaire S, Booth M, Gyarfas I, Iwane H, Marti B, Matsudo V etal. Development of public policy and physical activity initiatives internationally. Sports Med 1996; 21: 157-163.

[16] World Health Organization: The world health report 2002. Reducing risks, promoting healthy life Geneva: WHO; 2002.

[17] World Health Organization: Global Strategy on Diet, Physical Activity and Health WHA57.17. G eneva, Switzerland: WHO 2004.

[18] Troiano RP, Flegal KM, Kuczmarski RJ, Campell SM, Johnson CL. Over weight prevalence and trends for children and adolescents. Arch Pediatr Adolesc Med. 1995; 149:: 1085-1091.

[19] Epstein LH, Saelens BE, O'Brien JG. Effects of reinforcing increase in activity versus decreases in sedentary behavior in obese children. Intl J Behav Med. 1995; 2:41 - 50.

[20] Epstein LH, Saelens BE, Myers MD, Vito D. Effects of decreasing sedentary behaviors on activity choice in obese cjildren. Health Psychol. 1997; 16:107-113.

[21] US Department of Health and Human Services. Physical Activity and Health: A Report of the Surgeon General Atlanta, GA: US Department of Health and Human Services, Centers for Disease Control and prevention, National Centre for Chronic Disease Prevention and Health Promotion; 1996.

[22] National Institutes of Health Consensus development conference on diet and exercise in noninsulin dependent diabetes mellitus. Diabetes Care, 1987; 10:639-643. 


\section{G. Daradkeh et al.}

[23] Gortmaker SL, Sobal AM, Peterson K, Colditz CA, Dietz WH. Television viewing as a cause of increasing obesity among children in the United States. Arh pediatr Adolesc Med.1996; 150-536562.

[24] Raitakari OT, Porkka KVK, TaimelaS, et al. Effects of persistent physical activity and inactivity on coronary risk factors in children and young adults: the Cardiovascular Risk in young Finns study. Am I Epidemitol. 1994;140:195-205

[25] Trost SG, Pate PR Saunders R, Dowda M, et al. Gender differences in physical activity and determinants of physical activity in rural fifth grade children. jSch Health. 1996; 66:145-205.

[26] Trost SG, pate PR, Saunders R, Ward Ds, Dowda M, Felton G. A prospective study of determinants of physical activity in rural fifth grade children. Prev Med. 1997; 26:257-263.

[27] Sallis JF, Johnson MF, Calfas KJ, Caparosa S, Nichols JF. Assessing perceived physical environmental variables that may influence physical activity .Res Q Exerc Sport. 1997; 68:345351.

[28] Sallis JF, McKenzie TL, Elder JP, Broyles SL, Nader PR. Factors parents' usie in selecting play spaces for young children. Arch Pediatr Adolesc. Med 1997; 151:414-417.

[29] Baranowski T, Thompson WO, DuRant RH, BaranowskiJ, Puhl J. Observations on physical activity in physical locations: age, gender, ethnicity, and month effects. Res Q ExcerSport. 1993; 64:127-133.

[30] Klesges RC, Eck LH, Hanson CL, Haddock CK, Klesges LM. Effects of Obesity , social interactions, and physical environment on physical activity in preschoolers

[31] Bungum TJ, Vincent ML. Determinants of physical activity among female adolescents. Am J prev Med. 199713:115-122.

[32] Hill JO,Peters JC. Environmental contributions to the obesity epidemic science. 1998; 280:13711374.

[33] Sallis JF, Simons-Morton BG, Stone EJ, et al. Determinants of physical activity and interventions in youth. Med SciSport Exerc. 1992; 24 S248-S257.

[34] World Health Organisation: Global status report on non communicable disease Geneva: WHO; 2010.

[35] Ekelund U, Brage S, Froberg K, Harro M, Anderssen SA, Sardinha LB, Riddoch C, AndersenLB: TV viewing and physical activity is independently associated with metabolic risk in children: the European Youth Heart Study. Plos Med 2006, 3(12):e488.

[36] Al Hazza HM: Physical activity, fitness and fatness among Saudi children and adolescents: implications for cardiovascular health. Saudi Med 2002, 23:144-150.

[37] Al Hazza H: Prevelance of physical inactivity in Saudi Arabia: a brief review. East Meditter Health J 2004, 10:633-670.

[38] Laporte R, Montoye H, Caspersen C. Assessment of physical activity in epidemiologic research: problems and prospects. Public Health Rep 1985; 100:131-146.

[39] Al Hazza H: Prevelance of physical inactivity in Saudi Arabia: a brief review. East Meditter Health J 2004, 10:633-670.

[40] Laporte R, Montoye H, Caspersen C. Assessment of physical activity in epidemiologic research: problems and prospects. Public Health Rep 1985; 100:131-146.

[41] Montoye H, kemper H, Saris W, Washbburn R. Measuring Physical Activity and Energy Expenditure. Champaign, IL: Human Kinetics; 1996.

[42] American Academy of Pediatrics: Committee on public education. American Academy of Pediatrics: Children, adolescents, and television. Pediatrics 2001, 107: 423 - 426.

[43] Hazza N AL - Hazza, Nada Abahussein, Hana I AL -Sobayel , Dina M Qahwaji and Abdulrahman Musaiger. Physical activity, sedentary behavior and dietary habits among Saudi adolescents relative to age, gender, and region. International Journal of Behavioral Nutrition and Physical Activity 2011, 8: 140.

[44] Cui Z, Hardy LL, Dibley MJ, Bauman A: Temporal trends and recent correlates in sedentary behaviors in Chinese children. Int J Behave Nut Phys Act 2011, 8 (1): 93.

[45] Mark A E, Boyce WF, Janseen I: Television viewing, computer use and total screen time in Canadian youth. Pediatr Child Health 2006, 11: 595 - 599. 
[46] Tammelin T, Ekelund U, Remes J, Nayah S : Physical activity and sedentary behaviors among finnish youth . Med Sci Sports Exerc 2007, 39: 1067 - 1074.

[47] Caspersen C, Physical activity and coronary heart disease (Editorial) Phys Sportmed 1987; 15: $43-44$.

[48] Powell K. Population attributable risk of physical inactivity. In: Leon A, Editor. Physical activity and cardiovascular health - A National Consensus. Champaign, II: Human Kinetics; 1997: 40 47.

[49] Casperen C. Physical activity epidemiology: Concepts, methods and applications to exercise science. Exerc Sport Sci Rev 1989; 17: 423 - 473. Health psychol. 1990; 9:435-449. 